\title{
10 Golden Principles to Guide Your Succession Planning
}

\author{
Tom A. Rüsen (Witten Institute for Family Business (WIFU)) \\ Torsten Groth \\ Arist von Schlippe
}

KEYWORDS: Family Business, Succession, business

family.

There is no one-size-fits-all approach to family business succession. Every situation is different and every family is uniquely complex. However, some principles appear to transcend culture and other succession variables and apply to most circumstances.

In this short article, we've identified 10 golden principles for family business succession that if applied thoughtfully can smooth out the process and maintain family relations as a bonus.

\section{1 | Begin regular conversations about succession.}

Succession in many family businesses tends to be a hot mess of spoken and unspoken expectations. Part of the process inevitably includes objective evaluations of how family members are regarded and valued by other family members. That's a recipe for a swirl of emotions that can trip up the transition, given parents' desire not to make the wrong decision or disappoint a family member.

The sooner in the process that a family begins a conversation among its members, the smoother the transition. A conversation means that the topic is raised and discussed over time within the family. Treating succession as a taboo subject rarely advances the succession process. In fact, avoidance tends to keep kicking the proverbial can down the road. Avoiding making a decision becomes a decision - against succession.

Making succession a family conversation rather than a secretive decision by fiat relieves everyone of succession's existential weight. Parents no longer have to make the decision on their own, and their children do not have to commit to the business on a given day.

For example, one family, whom we will be referencing as a case example throughout this article, started "family business days" for their children at a very young age. The parents met at a fixed date every year together with members of the next generation. The discussion focused on new products and recent developments at the firm. During this day each family member expressed his/her view on the succession situation, their wishes and perceptions of what was needed.

In short, the children heard first-hand their parent's perspective on the business and its future. In turn, the parents heard their childrens' views about the business directly from the kids themselves. A regular fixed date enabled the family to keep in touch about the issue of succession at least once a year.

\section{2 | Separate ownership (shareholder) succession from leadership (management) succession.}

The two should not be conflated, and both are crucial to an efficient process of succession.

When issues of succession arise, families tend to concentrate on the operating business, since it demands management's attention every day. As a result, people think "succession" means handing over operational management. That is only one rail of succession, however. The other is shareholder succession. This should be a separate process, and families need to pay particular attention to it, since shareholders form the company's backbone.

Not thinking about shareholder succession can lead to problems -- such as when siblings, family clans, or patriarchs continue to dominate operations long after formally handing over their shares. That's a predictor for succession failure, and history is littered with such
Copyright $@ 2021$ The Authors. Entrepreneur \& Innovation Exchange is published at EIX.org. This is an open access article under the terms of the Creative Commons Attribution-NoDerivs License, which permits use and distribution in any medium, provided the original work is properly cited and no modifications or adaptations are made. View EIX.org Authorship Terms at https://eix.org/terms
FamilyBusiness 
stories.

Our case example family had survived (indeed, thrived) into the seventh generation. In the past, company shares and the CEO position were handed over to the first-born male, an artifact of patriarchal society. The company's size and value, however, made that impossible for the pattern to continue. Its leadership made the formal decision to separate shareholder succession from succession into top management. For each, a "succession track" was defined. For example, the succeeding generation was given shares at the age of 18 (legal adulthood in Germany) even though the decision of who might enter into management positions was not yet clear.

\section{3 | Pay attention to the financial, tax, and inheritance law implications.}

This may seem patently obvious, but the devil, as cliché goes, is in the details. The issues of management succession and transferring controlling shares can create a tsunami of financial, tax, and legal ramifications. The constantly changing regulations and provisions are complex, but here are several questions to start the process:

- Should there be anticipated succession?

- Do other siblings have to receive a compulsory portion (compensation) or are compulsory portion waivers required?

- Should a pension be part of the succession and, if so, how should this be regulated?

- Which tax-free allowances may be used?

-What effects will the application of tax exemption provisions have on the business?

- Do the articles of association have to be adjusted?

In our case example family, the succession of shares was adjusted according to inheritance law. Each member of the next generation signed at the age of $18 \mathrm{a}$ waiver of inheritance, so no compulsory part of the shares had to be given. Due to regulations of the family strategy and a charter, it was clear that there was no "right to inherit" but an obligation to serve the transgenerational wealth by the best suitable family member.

\section{4 | Focus on the business (separately from the family).}

What makes a family firm unique, of course, is the relationship with its shareholders, the family. Succession processes, however, tend to reveal the downsides of this so-called co-evolution. Family concerns can taint business decisions. An example is when decisions relevant to the survival of the firm are avoided because they might affect individual family members or disrupt family harmony.

One way to make sure that the business stays in focus is to ask a series of hypothetical questions:

- What would the business look like without the family?

- Which business decisions would be different in this imagined scenario?

- Which strategic and operative challenges would arise in this case?

The idea is not to eliminate or ignore the family, of course. The questions serve to scrutinize the current business, probing whether any underlying family-related considerations serve only to maintain family harmony. This assessment may also be useful in planning succession.

Family firms that survive for several generations place the business above family interests - when faced with a choice, which is most important. And they make the right decision without offending and discouraging family members in the process.

In the first principle, we used the example of how a family created "family business days" to help facilitate a conversation among its children about the business. Later in the succession process, the family divided its set-aside days into two parts: the first half of the day was focused on the demands, decisions, and strategic developments of the business only. The second half of the day we'll describe in the next principle.

\section{5 | Focus on the family (separately from the business).}

The previous principle does not eliminate the need to prioritize the family during the succession process. Each owning family faces a two-fold task: it must act for the benefit of the business and, at the same time, not lose sight of the well-being of its members. Family cohesion is a valuable asset and should not be jeopardized by succession. 
Succession decisions often create conflict among members in owner families. It only makes sense: decisions can offend close relatives and remain unforgotten and unforgiven even after decades. It's critical that the succession process include some thinking on the unique complexity of the family and its members. Here are several questions to help with this reflection:

-What would the family look like without the business?

- Which needs of family members become apparent?

- Which decisions affecting the family would be different without the family firm?

- Which issues and topics would the family have to prioritize?

A decision on succession requires striking a balance between business necessities and family needs. Every person in leadership should acknowledge and respect the unique internal dynamics of the close ties between business and family.

Back to the example of the family business days: In the second part of the day, the time was devoted to family internal topics, such as onboarding new partners and addressing visible family dynamics.

\section{6 | Prioritize competence over birthright.}

This principle is another one that seems patently obvious, but in a family business, it's not always selfevident. Many families (roughly half in a recent study) still prefer succession within the family (Schwartz, 2018). Some families cling to the hope of appointing a candidate from the family, even when the children are not qualified or show no interest in working in the business.

Here are a series of questions to help families sort through the issue of competency:

- Which competencies would you expect of a manager who is not a relative?

- Would I consider my (family-internal) successor to be qualified if he or she were not a family member?

- Is there any reason not to conduct a special assessment process for interested members of the next generation?

- Who can act as an external and neutral authority for the decision about satisfying the necessary competency and experience requirements? Are there any qualified advisory council members? Can the family agree on a neutral assessment procedure?

- What especially characterizes the business family's current mental model? How can change be initiated?

The rule of thumb for succession is this: competence before birthright. As a corollary principle, the family should never decide on the suitability of family members alone. External experts or a human resource committee can add an objective perspective to the process. For managerial succession, members of the next generation should always exhibit a level of competence comparable to that of a potential external manager.

Through this article, we've used the case of a seventhgeneration family. Its leadership required the next generation to be evaluated against external benchmarks. When showing interest in a management position, each member of the succeeding generation had to go through an assessment center, which evaluated their skill set according to the business needs defined by the supervisory board.

The results defined a clear development plan with continuous coaching by external familial members of the board. At the end of the process, the coaches were asked about the competence level of each family member, the same vetting process that any external top management hire undergoes.

\section{7 | Allow successors to seek their own path.}

Most parents aspire to raise children who will forge their own life path -- until that child becomes a successor. It can be excruciating to let go. Business-owning parents, however, should honor their child's unique approach to the business. In previous generations the typical development of a successor was in-house training as well as learning the ropes at a friendly company -. perhaps a supplier or customer -- within the same industry.

Newer forms of succession suggest different forms of development for members of the rising generation. Often, next generation members now collect their 
business experiences far afield from their parents' business. They may participate in start-up businesses or social entrepreneurship. Experience in technology start-ups or other technology-based businesses will be indispensable later on if the family business embraces digitalization.

In our case example family, younger members of the next generation were required either to act as cofounders of a start-up or work in entrepreneurial environments before working at the family business. A minimum of 18 months in this environment was part of their educational program to become a top management successor.

\section{8 | Actively support and encourage successors (as well as incumbents) during the transition process.}

Many successors fret about the expectations placed on them after the transition is complete. They feel the full weight of responsibility as they start to lead the business. While it's crucial to recognize the individuality and independence of the successor generation, they also need support.

One kind of support is an ongoing dialogue with the outgoing leaders, who know first-hand the emotion and burden of proving their business competence to their parents or third parties. An ongoing dialogue can build solidarity and trust between parents and children and help correct the painful experiences of the past and prevent them from happening in the future. Sons and daughters won't have to think of the business as a burden and/or a threat, but as a challenge that enables them to form their own learning and life experiences. Within our case family, the next generation had coaches and advisors from the board as well as succession specialists who served as regular sparring partners and "reflectors."

The relinquishing generation also needs some space for reflection.

They often feel as if others believe they are the problem, an impediment to change. They may feel cheated out of recognition for their life's work. When participating in discussions about the successor generation, the senior generation often longs to tell their story to the family. It's important that the successor generation honors the outgoing leaders by creating opportunities to reflect on their leadership journey.

In our case family, the incumbent leaders found support from a small community of senior generation members of other business families. In short, the group became a kind of peer support group of senior family executives, all of whom were "learning to let go." Members felt comfortable raising questions, asking for advice, and offering wisdom and counseling.

\section{9 | Consider alternatives to family successors.}

Whether children assume executive leadership in a family business is secondary to keeping the business viable. While it's understandable that families may prefer to keep the business in the family, they have many alternatives to traditional family succession. Apart from appointing external managers, other options include management-buy-out and management-buy-in, selling to another company, an IPO, or establishing a foundation.

Early on in the succession process, our case family installed a family external management team, a hedge in case the next generation lost interest or the younger leaders had not achieved competency. Along with this policy, an HR management practice was installed to identify junior staff members from within the company to fill potential gaps within the top management team in the future.

\section{0 | Put a high value on external advice.}

Handing over a family business is incredibly disruptive in the life of a family. Ways of doing things that worked well for decades are questioned. The earlier generation is suddenly no longer in command. Instead, the son, daughter, or another family member hold the reins. The status quo is gone - for employees as well as family members.

Given these wrenching changes, most families would benefit by engaging external advisors and coaches to help them through the transition, whether briefly or over a longer period. This makes obvious sense regarding legal and tax matters, but even more so for the relationship and communication issues surrounding succession.

For example, an external coach could facilitate a regular 
date and time to discuss potential hot spots between the incumbent and new generations. This can minimize problematic conduct, insults, and other undesirable developments. The senior and junior generations thereby create a kind of platform to reflect on the succession process undisturbed, i.e., to observe each other's behavior and agree on necessary changes.

Seeking outside help is not an admission of weakness. On the contrary, it demonstrates a responsible approach to the most important decisions in the life of businesses and their families.

Our case family regularly invited experts to their family business days and had additional coaches and advisors with whom they reflected on upcoming questions. They had an entire team of trusted advisors consisting of specialized consultants, experienced family business owners, and members of their supervisory board.

Acknowledgement: The authors would like to thank Dave Goetz and Melissa Parks of Journey Sixty6 (www.journeysixty6.com

(http://www.journeysixty6.com/) ) for their invaluable help with preparing this article.

\section{References}

Groth, T., Rüsen, T. A., Schlippe, A. v. (2020):Securing succession in a family business across generations How succession may be organized in businesses and among shareholders Practical Guide of the Witten Institute for Family Business (WIFU). Witten: WIFU (free fulltext(https://www.wifu.de/en/bibliothek/securing-

succession-in-a-family-business-across-generations/) ).

Otten-Pappas, D. (2015): Taking over the Family Business - A carreer developmental perspective on male and female succession. Book No. 16 WIFU Publication Series edited by Tom A. Rüsen, Heiko Kleve, Arist von Schlippe. Göttingen: V\&R unipress (free fulltext(https://www.wifu.de/en/bibliothek/takingover-the-family-business/) ).

Pieper, T. M. (2021): The Importance of Family Cohesion for Long-term Family Business Survival. In: Rüsen, T. A. (Eds.) Theory and Practice of Business Families and Family Businesses - Commemorative Publication for Arist von Schlippe. Göttingen: Vandenhoek \& Ruprecht (P. 157 - 163) (free fulltext (https://www.wifu.de/en/bibliothek/theory-and-practiceof-business-families-and-family-businesses/) ).
Rüsen, T. A. (2020): Professional ownership in business families - the success factor for long-lasting family businesses. Practical Guide of the Witten Institute for Family Business (WIFU). Witten: WIFU (free fulltext(https://www.wifu.de/en/bibliothek/professionalownership-in-business-families/()).

Rüsen, T. A. \& Löhde, A.-S. (2021): The Business Family and its Family Strategy - Insights into the lived Practice of Family Governance. Study of the Witten Institute for Family Business (WIFU). Witten: WIFU (free fulltext(https://www.wifu.de/en/bibliothek/the-businessfamily-and-its-family-strategy/) ).

Rüsen, T. A.; Schlippe, A. v. \& Groth, T., Gimeno. A. (2020): Mental Models of Family Businesses - How Business Families see themselves and their connection to the Family Business. Practical Guide of the Witten Institute for Family Business (WIFU). Witten: WIFU (free fulltext(https://www.wifu.de/en/bibliothek/mental-modelsof-family-businesses/()).

Schlippe, A. v., Rüsen, T. A., Groth, T. (2021): The Two Sides of the Business Family. Governance and Strategy Across Generations. Cham: Springer International Publishing. 